\title{
The effect of resource based view on sustainable capability advantage
}

\author{
Mostafa Jafari and Fatemeh Rezaee*
}

Department of Industrial Engineering, Iran University of Science and Technology, Narmak, Tehran, Iran \section{H R O N I C L E}

Article history:

Received June 4, 2014

Accepted 29 October 2014

Available online

November 12014

Resource based view

Banking industry

Sustainability capability

Advantage

\section{A B S T R A C T}

\begin{abstract}
Nowadays, it is important to achieve and to sustain an organization's competitive advantage in complex environments. This paper evaluates different concepts that have led to such benefits. The study sheds light on resource based view (RBV) and its role to reach sustainable competitive advantage (SCA) within banking industry of Iran. A valid research instrument was utilized to conduct a survey of 150 top- and middle-level managers from Mellat bank of Iran. With a response rate of 81.3 percent, 122 questionnaires were returned while a number of valid and usable questionnaires were 101. In order to determine validity of questionnaire, the content validity and Cronbach's alpha were used to determine the reliability of the questionnaire (RBV questionnaire 0.934, SCA questionnaire 0.843). The study utilized structural equation modelling, and a series of exploratory and confirmatory factor analyses and they tested the integrated model of MKM and SCA. Statistical support was found for the hypothesized relationships. Moreover it has been shown that RBV had the greatest effect on the market centered SCA, while it had the least influence on the financial centered. The findings offer valuable insights on the generalizability of MKM in a research setting. Structural equation modeling has been implemented and the study also used freedman test to rank the factors and the results show that tangible assets was the most important factor $(0.71)$, followed by intangible assets (0.70), human resource capability (0.69), executive capability (0.64) and management capability (0.62) was the last important factor.
\end{abstract}

\section{Introduction}

Banking industry plays an important role in developing economies not only in economic development, but also in poverty alleviation and economic problems reduction. In addition, banking industry has been considered as an important strategic sector in Iran for building high economic growth, reducing unemployment, inequality and inflation. However, Bank is also a complex and has multidimensional characteristics, but its performance is a focal sector in business studies of any country. Performance and subsequently to reach sustainable competitive advantage is normally characterized as a bank's capability to build acceptable outcomes and actions. For banks, reaching improved performance not only depends on the successful deployment of tangible as well as intangible assets and capabilities but also on the effective management of this sector (Barney, 1991).

*Corresponding author. Tel: 98-913-1861455

E-mail addresses: fh rezaee@iust.ac.ir, fh rezaee@yahoo.com (F. Rezaee) 
Banks have their own rules in the economy, as one of the most essential economic sectors. Therefore, not only banks require improving themselves through assets management in their pursuit for excellence, but also governments need to appropriately and timely support them. One of the most recent and controversial issues of research pertaining to corporate strategy such as banks known as the resource based view (RBV). RBV has absorbed considerable research during the last few decades (Penrose, 1959; Wernerfelt, 1984; Barney, 1986, 1988; Dierickx \& Cool, 1989; Rumelt, 1991; Conner, 1991).

In the 1980s and 1990s, RBV was suggested a unified and novel theoretical framework for the corporate research stream, which emphasizes on the relative importance of organization resources. In addition, RBV quickly emerged as the key theoretical foundation that fueled a thriving development in the literature of strategic management (Wan et al., 2011). According to RBV, the accumulation of valuable, rare, inimitable and no substitutable (VRIN) resources is the basis of enterprise competitiveness (Peteraf, 1993). Barney (1991) stated the concept of resources could include all assets, capabilities, organizational processes, organization attributes, information, knowledge, etc. In addition, he argued the resources were controlled by an organization, which enables it to use strategies that enhance its efficiency and effectiveness. RBV recommends that the resources possessed by a firm are the primary determinants of its performance, and these may contribute to a sustainable competitive advantage of the organizations (Hoffer \& Schendel, 1978 cited by Akio, 2005). Accordingly, the purpose of this paper is to examine the relationship between RBV and SCA of organization in banking industry of Iran. The paper is organized into six sections including Section 1. Section 2 presents the literature review and the hypotheses of this study. Section 3 describes the research methodology. Section 4 presents the results and finally, Section 5 implications of the study.

\section{Literature review}

The issues concerning firms have been more dynamic and changing over time. Each organization should learn the changes in the available resources so that they could overcome competition and gain competitive advantage in this continuously changing world. Therefore, it is undoubtedly needed to build resource based view as an organizational process to reach such a competitive advantage. In continuation, the core processes of RBV (tangible assets, intangible assets, executive capability, human resource capability, management capability) and SCA (market, costumer, finance) as well as relationship between these items are stated. The study has a practical significance for policy makers of firms in banking sector of Iran for understanding their success in relationships with customers, market and finance and for effectively positioning their organization's competitive advantages.

\subsection{Resource based view (RBV)}

Further consideration in success organizations would lead to the relationship between the success of an organization in the market and resources of that organization. One of the views that seek to answer the question is RBV. According to this theory, resources are heterogeneous and heterogeneity can sustain over time. It explains how some organizations are able to earn super profits (Lockett et al., 2009). In other words, RBV is largely concerned with how firms generate and sustain competitive advantage (Ambrosini \& Bowman, 2009). In fact, two fundamental assumptions underlie RBV. First, organizations owns various resources and capabilities, and some organizations within the same industry may do certain activities better than the others based on these resource differences (Barney, 2001a). Second, resource differences among organizations can be persistent due to rarity and difficulties in acquiring or imitating those resources and capabilities (Barney, 2001b). According to the view rival firms compete on the basis of the heterogeneity and immobility of their resources and capabilities (Peteraf \& Bergen, 2003; Marr \& Moustaghfir, 2004). 
Makadok (2001) and Kozlenkova, Samaha and Palmatier (2014) defined capabilities as a special kind of resource, specifically an organizationally non-transferable resource whose purpose was to progress the productivity of the other resources possessed by the organization. Resources can be physical, human and organizational in nature (Grant, 1996). Amit and Schoemaker (1993) believed resources could be divided into assets and capabilities, which capabilities are either process by which the resources are utilized. In fact, it is recommended that resources, which are tangible assets, intangible assets and capabilities, maintain the potential to provide firms with a sustainable competitive advantage. Assets that have a physical form are tangible assets include both fixed assets, such as machinery, buildings, land, real estate, vehicles, equipment, and precious metals and current assets, such as inventory and currencies. Intangible assets include both nonphysical resources, such as patents, trademarks, copyrights, goodwill, brand recognition, and computer programs that have a value to the firm and finance assets, including such items as accounts receivable, bonds and stocks. In this respect, capabilities are used to engage the resources within the firm, such as implicit processes to transfer knowledge within the firm (Hoopes et al., 2003; Acroush, 2010).

Generally, RBV argues resources that are simultaneously valuable, rare, inimitable, and nonsubstitutable (VRIN) are sources of competitive advantage (Barney, 1991). Valuable resources have to enable an organization to engage a value creating strategy by either reduce its own weaknesses or superiority over its competitors (Villalonga \& Amit, 2006). There are many methods that the valuable resources of an organization can be evaluated. For instance, organization's valuable resources enable it to develop and implement strategies that have the impact of reducing an organization's pure costs or the creativity and innovativeness of an organization in developing new products (Mahoney \& Pandian, 1992; Rose et al., 2010). Relevant in this perspective, rare is "If the number of firms that possess these substitute resources is large, then the strategies that are associated with them are not rare, and thus not a source of superior performance and If the number of firms that possess these substitutes is small, they can still have competitive advantage implications" (Barney \& Arikan, 2001). It can be said to define the inimitable, if a valuable resource is controlled by only one firm it could be a source of a competitive advantage (Barney, 1991; Talaja, 2012).

If competitors could not duplicate the rival strategic, this advantage could be sustainable (Peteraf, 1993). In fact, imitability is linked to the characteristics of organization: i.e. corporate culture, unique historical conditions, managerial capabilities, property rights, information asymmetries and casual ambiguity - degree to which decision makers understand the relationship between organizational inputs and outputs and their argument is that inability to understand what causes the superior performance of competitors (King, 2007). According to Rindova et al. (2010), firms can gain competitive advantage under conditions of high ambiguity, social complexity, large number of internal resources are being used for examples of interpersonal relationships, traditions and etc. (Wernerfelt \& Montgomery, 1986), isolating mechanisms, are reflected in the different aspects of corporate such as managerial capabilities. According to Rugman and Verbeke (2002), focus on creating isolating mechanisms could be the cause sustainable rents, company reputation, track progress of a company has earned and accumulated over time as a competitor could not perfectly imitate, and so on. Ultimately, these characteristics will result in a competitive barrier and help to reach a sustainable competitive advantage. An organization should protect resources that possess characteristics of sustainable, because not doing so can be potentially replaced by alternative sources. In other words, the sustainability of a firm's asset position hinges on how easily its resources can be substituted. If the resources possessed by an organization can easily be replicated by competitors then the advantage will not last long. RBV should focus on the ability of the organization to sustain a combination of resources, which could not be possessed or built up in a homological way by competitors. Any organization should in depth analyze ways to avoid imitation of their resources in order to reach SCA. 


\subsection{Competitive advantage}

Although there are many different viewpoints between the discussed theory the very RBV, they are all similar in one way on maximizing the organizational competitive advantage and improving the organization's position among their competitors. There has been a long dispute about how organizations could reach to sustainable competitive advantage. In addition, many experts have revealed their opinions for such a matter including porter, which believed that cheap labors and natural resources are not good economy requirements (Porter 1985 sited by Andersen, 2013). He expressed that a competitive advantage was the ability obtained through resources and attributes that helps a firm perform at a higher level than the other competitors in the same industry or market (Chacarbaghi \& Lynch, 1999 sited by Josiah, 2013). When a firm has reached a competitive advantage and prevents imitation by competitors, resisting erosion by competitor behavior and achieving sustainable competitive advantage is considered as an obvious result. However preventing imitation is not permanent; the firm should make any effort to delay this occurrence to gain the maximum benefit from its competitive advantage (Reed \& Defillippi, 1990; Pearce \& Robinson, 2000; Christensen, 2001; Chunxia, 2012). Barney argued that a firm had a competitive advantage when it implies a value creating strategy while any current or potential competitors are deprived to implement the strategy simultaneously and they are also not capable of duplicating that (Barney, 2000). Lippman and Rumelt (1982) stated that a firm competitive advantage is assumed as a sustainable paradigm as long as competitors are unable to duplicate it, in this sense it would not last if they become aware of how they can imitate it. It has to be noted that industry type has a significant effect on a period of calendar time that a firm enjoys a concept of sustained competitive advantage so that sustainability lasts longer in high-tech industry than other Industries.

Prahalad and Hamel (1990) reported that Western and Japanese companies try to standardize product cost and quality. Although this competency could be considered as an option to a firm, today it is not dramatically emphasized as a real source to gain a competitive advantage. In other words, cost and quality cannot be ignored as an enabler to a firm to overcome competitors such that it could derive competitive advantage. Prahalad and Hamel (1990) identified whether a service quality of Pakistan telecom results to a firm competitive advantage absorbing customers and becoming a sustainable competitive advantage through a period of time. The study demonstrated that the telecom industry has a low rating on empathy, personal attention to customers and understanding their needs. The question of what leads to a successful business is not only about today's economic crisis, but also is a question that each company should follow to find a feasible answer (Oliver, 2000). Zook and Allen (2001) argued that having a profitable and differentiated company obtained through some source of competitive advantage is extremely required to make a sustained and profitable growth. According to Reed and Defillippi (1990) the sources of competitive advantage are as numerous as firm activities. A survey including a study of 59 articles in 8 fields (strategic management, strategic management of marketing, marketing management, information technology, knowledge management, resourcesbased theory, entrepreneurship, and human resource management) demonstrated that among Porter's triple strategies, the strategy of differentiation has captured highest attention (Hamidizadeh \& Taheri, 2013). A successful company should focus on its core competence and invests in development of activities creating value and reaches core competence that is the source of comtetive advantage. Core competence is considered as a fundamental concept for competitive strategy in a highly competitive market identified as knowledge set helping a company to perform in a different way from competitors and results in a competitive advantage. The core competence concept has been implemented to an organization identifying and efficiently utilizing its strength. Gupta et al. (2009) further argued that core competence was a collection comprised of communication, involvement and a deep commitment across organizational boundaries. Ljungquist (2008) demonstrated that core competence could be emerged to justify business diversity at large companies and provide support for some internal processes including product development. Prahalad and Hamel (1990) introduced companies' ability 
as a real source of competitive advantage empowering business to overcome competitors through rapidly changing environment by consolidating technologies and production skills into competence. It has to be emphasized that a firm could reach sustainable competitive advantage if it enjoys having rare, unique and none-replaceable resources. Gupta et al. (2009) point out these resources are not generally capable of creating a competitive advantage, which is in higher level than others. A company may need to answer the question of how it can use available sources and how to create new resources and finds a new approach to develop a new type of product and finally these resources which are considered as a special form of final products and services should create a competitive advantage to a firm and should contribute to the firm's value creation.

Surveys such as that conducted by Holliday (2001) show that sources of firm's competitive advantage should be supported by human factors. According to his argument, social barriers including organizational classes, knowledge management, leadership styles, work teams and etch, have a more considerable effect on effective use of the sources than even strategic barriers. Leadership is a most effective component of a companies' competitive advantage that should not be ignored easily (White $\&$ Moraschinelli, 2009). In other words, there is not any other entity with such an important effect and influence on the management (Burns, 2008). Trung (2014) believed that a strategic position of a companies' management is forecasting the market trend and obtaining sustainable competitive advantage to improve companies' position among competitors.

\subsection{Ensuring of competitive advantage}

In some cases, it is impossible for competitors to imitate. However, it is quite rare. Physically unique resources made by human resource through their ability are good examples in such a case (Pearce \& Robinson, 2000); but imitation is one of the most challenging issues for an organization trying to sustain a competitive advantage. Therefore, a firm should invest on raising a barrier to imitation in order to ensure sustainability of competitive advantage. Although it is inevitable that a competitive advantage is not quite sustainable by itself and finally competitors can find a way to realize how they can imitate the strategy using by the firm (Christensen, 2001). However, there is no insuperable barrier to imitation, a firm has to prolong the competitive advantage with emphasis on two proposed strategies as follow. First, organizations should make their effort preventing competitors comprehend the foundation of their strategy and realize how they create the competitive advantage. Second strategy is to use an array of activities instead of using a single activity. This means matching an array of interlocked activity and making an ambiguous strategy to implement which one is harder for the competitors to duplicate. As this approach reduces the probability of competitors' imitation, it may ensure the competitive advantage.

\subsection{Sustainable competitive advantage}

Reaching a competitive advantage has been a matter of significance to a firm since before and much attention has been paid to this issue by a wide range of experts and specialists. According to literature review and experts views on the subject, the mentioned measures have been classified into three categories comprised of market, finance and customer and then have been fairly surveyed more. A sustained competitive advantage is achieved through unique values, which are creating a strategy that any other current or potential competitor is unable to imitate or imply it simultaneously and finally the using strategy cannot be duplicated for long period of time.

\subsubsection{Customer}

A core competence defined as a skill enabling a firm to create a fundamental value and leads to customer loyalty have to result to customer perceived value. Studies show that customer loyalty and customer attention are two challenging concepts that all organizations encounter. It is exactly clear 
that loyal customers can raise sales and customer share and reduce costs and higher prices (Alrubaiee \& Alnazer, 2010). Our study seeks to address two critical dimensions of competitive advantage with focus on customers, including flexibility and responsiveness. Flexibility refers to organization capabilities to provide a superior customer value (Johnson et al., 2008) and responsiveness is defined as an organization ability to respond fast to their customers' wants and needs (Carlos et al., 2010). A competitive advantage can be obtained through meeting organizational objectives and customers' needs in a highly competitive environment (Evans et al., 2006). Therefore, organizations should fight against each other for capturing customer attention and making a loyal customer. In other words, a competitive advantage is obtained when customer needs and wants are met more effective and efficient than competitors for a long time by a company, however their competitors make attempt to duplicate, reproduce and even surpass the competitive advantage.

\subsubsection{Market}

Li and Zhou (2010) investigated how market orientation and managerial tie could influence on competitive advantage. This research showed that one of the most important dimensions of a firm's competitive advantage was institutional advantage, which means an organization's superiority in obtaining rare sources and institutional support. In this context it is stated that brands and corporate images had a significant impact on sustained competitive advantage required for a highly competitive environment (Seetharaman et al., 2001; Amini, 2012).

\subsubsection{Finance}

Reaching a competitive advantage results to a position for a company to achieve and sustain above average profitability for some years (Jones \& Hill, 2013). It has to be noted that a profit is gained through sales incomes results from customer purchase (Rijamampianina et al., 2003; Thompson et al., 2012).

\section{Research model and hypotheses}

Derived from the existing literature, the proposed relationships among resource based view and factors of sustainable competitive advantage in the banking industry are discussed and hypotheses related to these variables are developed. Their search framework generated in this study is illustrated in Fig. 1. This framework briefly proposes that the five different items of RBV in the banking industry will enhance its SCA, which will then improve market, customer and finance performances. This paper aims to investigate the underlying influencing mechanism between RBV and SCA in the banking industry. It examines what types of components are most crucial to be converted into competitive advantage through RBV, describes and understands factors of SCA and determines relationship between RBV and SCA in the banking industry of Iran. Therefore, this paper proposes three following hypotheses.

Hypothesis 1. Resource based view (RBV) is positively associated with Market centered sustainable competitive advantage (MSCA).

Hypothesis 2. Resource based view (RBV) is positively associated with customer centered sustainable competitive advantage (CSCA).

Hypothesis 3. Resource based view (RBV) is positively associated with finance centered sustainable competitive advantage (FSCA). 


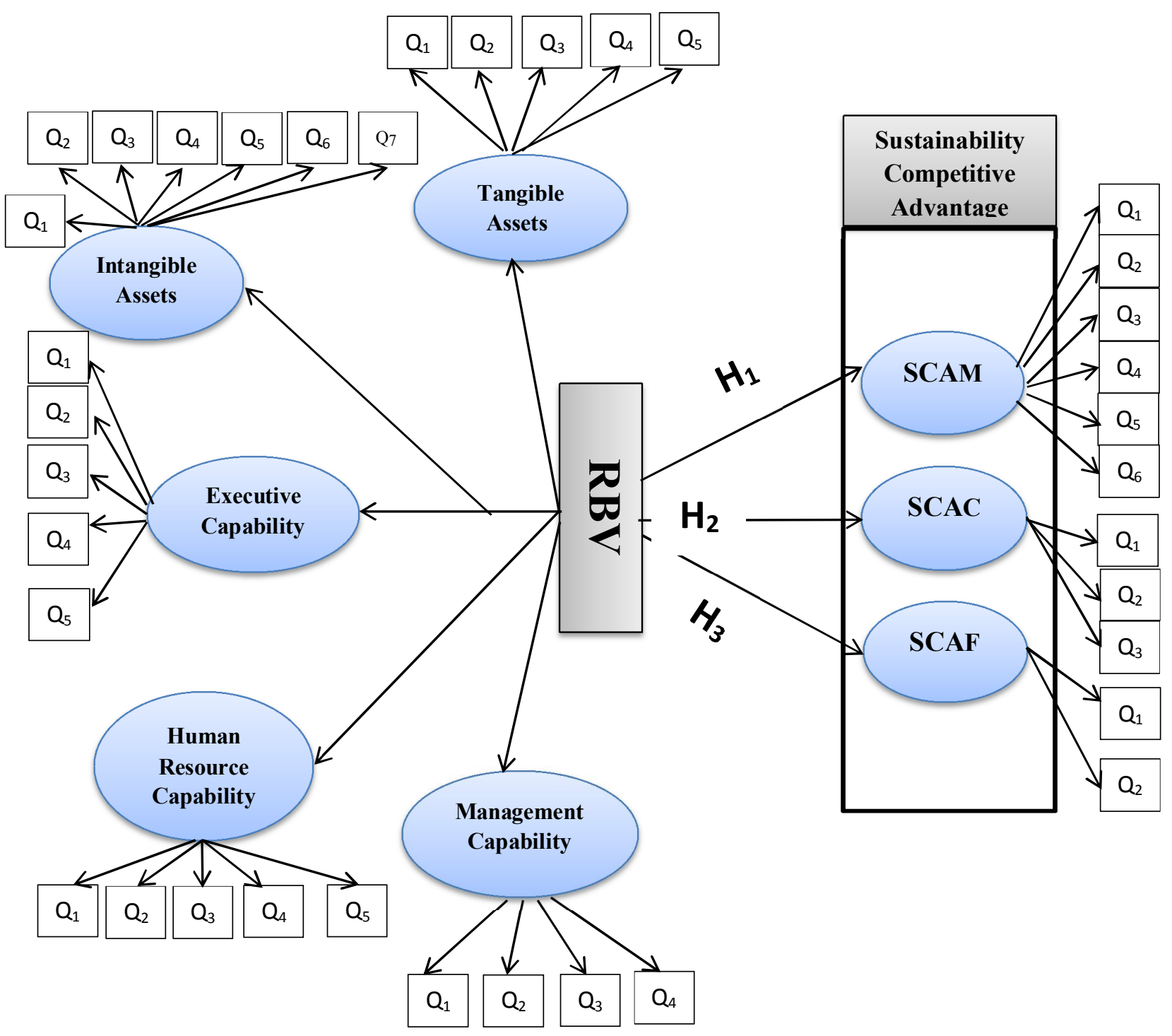

Fig. 1. Conceptual model between RBV and SCA

\subsection{Methodology}

In this section, the sample, procedures of data collection, operational measures of variables and statistical analyses are studied in order to determine the links between the RBV and SCA. The banking industry is a major part of Iran's economy. MBI is witnessing considerable growth and is characterized by fierce competition which makes it a suitable locale for research to examine the influence of RBV on SCA in the banking industry. MBI was established on 1979 by virtue of the resolution dated 1979 adopted by the General Assembly of Banks and pursuant to the provision of article 17 of the Bill on administering the Banks, with a paid up capital of Rls 33.5 bn as a merger of ten pre-revolution private banks comprising: Tehran, Dariush, Pars, Etebarat Taavoni \& Tozie, Iran \& Arab, Bein-al-melalie-Iran, Omran, Bimeh Iran, Tejarat Khareji Iran, and Farhangian.

Currently, the bank's capital amounts to Rls 40000 bn and is one of the largest commercial banks in the Islamic Republic of Iran, ranking among the top 1000 banks of the world (Iranian Banks). As an effort to ascertain the content validity of the survey questionnaire, a draft survey was pre-tested by both academicians (i.e. two Strategic Management Assistant Professor) and practitioners (i.e. ten managers' Bank). The participants were requested to evaluate the survey questionnaire on its 
wording, clarity and relevancy. Ultimately, the final version of questionnaire was distributed randomly to those who are in the executive or Senior Managers, specialists and consultants from the administration and improvement methods, marketing, strategy, risk management and operations manager department of MBI. The reason of choosing this group of professionals as the unit for analysis is because they are the most knowledgeable in terms of the research issues of the study. From the total of 150 questionnaires circulated, 122 were returned with complete answers, which represent a response rate of $81.3 \%$. The number of valid and usable questionnaires was 101 . Fig. 2 shows the company characteristics and the target respondents. Fig. 2 shows that the majority of Respondents, 81.1 percent, are males that are consistent with the Iranian society which is still relatively a male dominated especially on the top management positions. The majority of managers are middle-aged and well educated. This is consistent with the Iranian society that is described as Middle-aged and enjoys high levels of education in the bank department. Being well educated would greatly help MBI in building and accumulating RBV to reach SCA now and in the future. Also, Fig. 2 shows that the majority of managers, 67 percent, are well experienced in this industry and have more than ten years of experience. This holds a strategic implication that indicates that MBI has relevant and sufficient business industry experience that is crucial for building and sustaining assets and capabilities as a source of competitive advantage for a long time. Finally, Fig. 2 shows that 61.6 percent of managers have business education background which indicates there is reasonable recruitment process in the bank that focus on quality of people as one of their major assets to achieve a success.
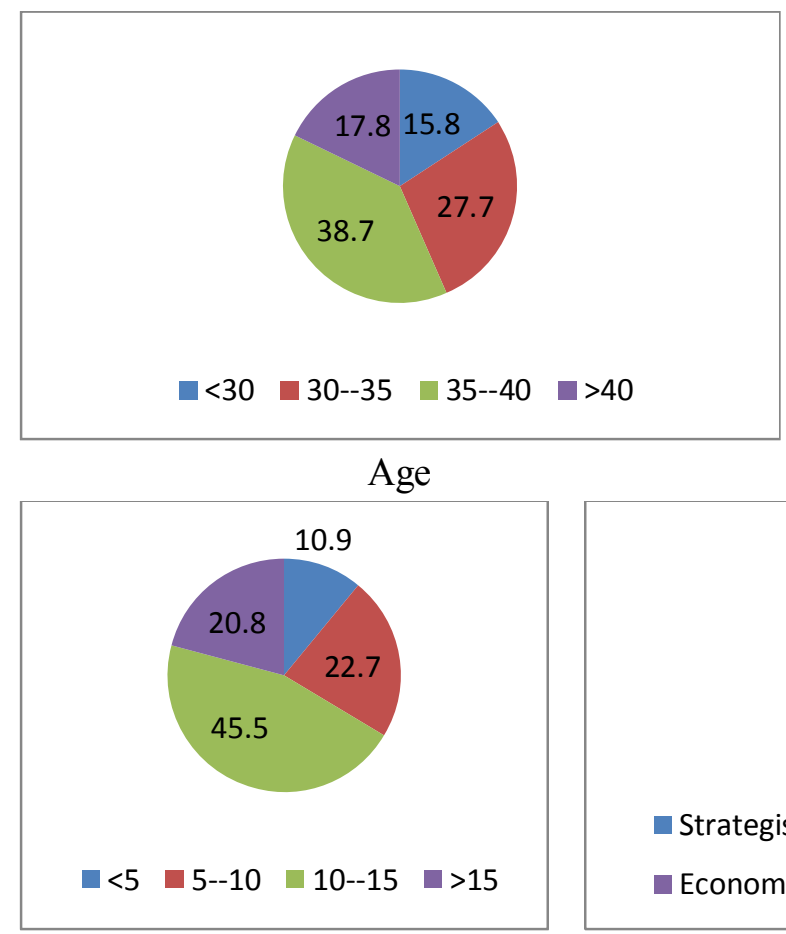

Job experience

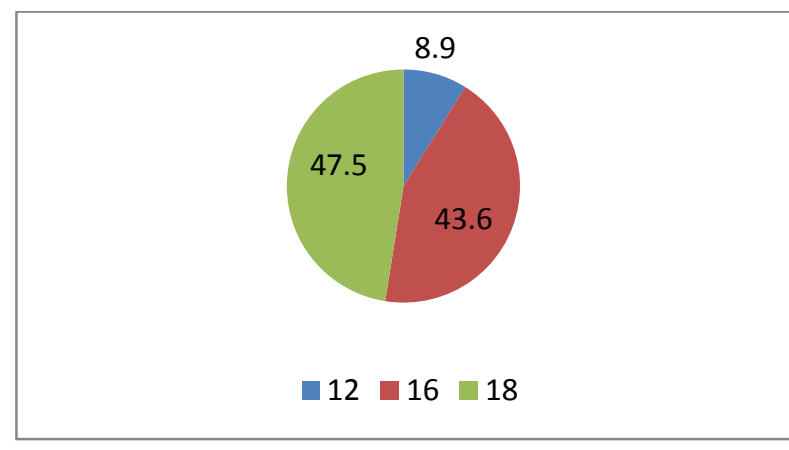

Years of education

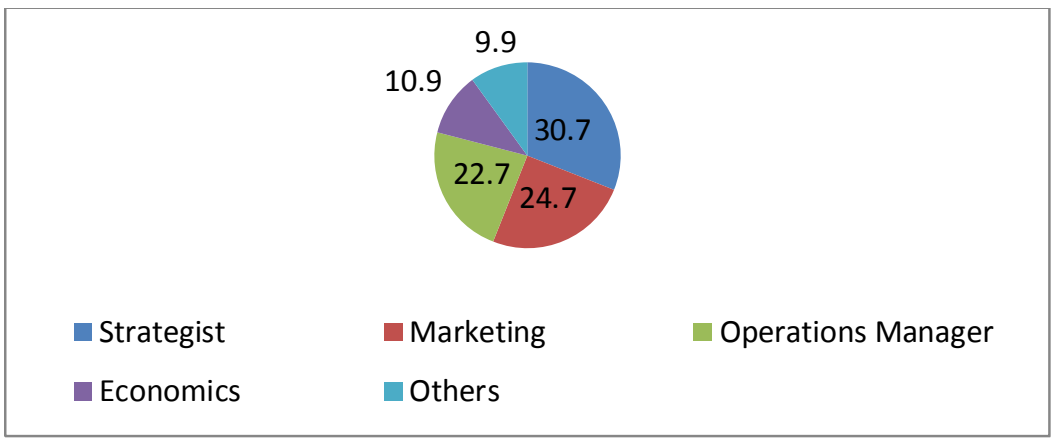

Job title

Fig. 2. Personal characteristics of the participants 
The part of measure is organized into two sections that present how to measure the dimension of each construct. It should be mentioned, in order to assess the precision and focuses of the respondents, some questions were designed negatively.

\subsection{Measure of $R B V$}

Five resource based view dimensions including: tangible assets, intangible assets, executive capability, human resource capability, management capability were evaluated in this study. These RBV dimensions were selected based on the studies carried out by Barney (1999). Each of these RBV practices was measured via a five-item, 5-point Likert scale ranging from strongly disagree $=1$ to strongly agree $=5$.

\subsection{Measure of $S C A$}

Porter (1979)'s conceptualization of SCA seems to dominate the literature (Reed \& Defillippi, 1990; Porter, 1996; Pearce \& Robinson, 2000; Christensen, 2001). The instrument of SCA has been used to assess SCA across various competitive advantage settings. Thus the three area of SCA were chosen to represent the SCA dimensions in the present study as a result. A review of the literature concerning the sustainable competitive advantage in service institutions such as banks found that most research assessed the construct of service institutions from the market, costumer and finance perspective. These studies include Johnson et al. (2008), Carlos et al. (2010), Li and Zhou (2010), Jones and Hill (2013) and Trung (2014). Despite the market, customer and a finance-centre approach for service delivery, very few studies indeed have measured sustainable competitive advantage from these perceptive. The paper focuses on studies investigating the association between areas of SCA and RBV. The construct measurement is by using a five-item index, which includes the three fundamental constructs of SCA (i.e. market, customer, finance). Each of these SCA practices was separately measured and analysis. In order to measure respondents' perception towards the SCA within bank, a 5 -point Likert scale was developed ( $1=$ strongly disagree; 5 = strongly agree).

In this study, a Structural Equation Modelling (SEM), Exploratory Factor Analysis (EFA) and Confirmatory Factor Analysis (CFA) were used on the multi-item measure in this study. In order to perform the SEM technique, the data analysis was performed in five steps: first is check of normality assumption, second is to examine the KMO and Bartlett's test, third, is to perform the exploratory factor analysis, forth, is to carry out the confirmatory factor analysis and finally, is examining the hypotheses through SEM. Prior to the analysis of the data, the normality assumption is used in the data preparation stage. One of the main functions includes checking multivariate normality to determine if a data set is well modelled by a normal distribution. Normality test was achieved through skewness $< \pm 2$ and kurtosis $< \pm 2$. In this study, the amounts of skewness and kurtosis were the ranges. However, these ranges may be considered smaller or larger by different scientists of statistics. Furthermore, the Shapiro-Wilks tests were also used to verify the existence of normality, in which null-hypothesis of this test is that the data are normally distributed and if the p-value is more than the chosen alpha level (i.e. 0.05), then the null hypothesis is accepted and there is some evidence that the data tested are from a normally distributed. The result revealed the normal distribution of the data since the $\mathrm{p}$-value is greater than 0.05 . The $\mathrm{p}$-value in this study is more than 0.05 and thus can assume that the model satisfactorily fits a normality distribution (Razali \& Wah, 2011). In the next section, the problem of KMO and Bartlett's Test being carried out to establish the correlations among variables. Is the strength of the relationship among variables large enough? Is it a good idea to proceed a factor analysis for the data? Factor Analysis can reply to these questions with KMO and Bartlett's Test. The Kaiser-Meyer-Olkin (KMO) measure of sampling adequacy tests whether the partial correlations among variables are small. The Kaiser-Meyer-Olkin measure of sampling adequacy is an index for comparing the magnitudes of the observed correlation coefficients to the 
magnitudes of the partial correlation coefficients. Another indicator of the strength of the relationship among variables is Bartlett's test of Sphericity. Bartlett's test of Sphericity tests whether the correlation matrix is an identity matrix, which would indicate that the factor model is appropriate. This test is used to test the null hypothesis that the variables in the population correlation matrix are uncorrelated. The KMO measures the sampling adequacy which should be greater than 0.5 for a satisfactory factor analysis to proceed. Looking at the Table 2 and 3, the KMO measure is 0.865 and 0.820 for RBV and SCA, respectively. Large values for the KMO measure indicate that a factor analysis of the variables is a good idea. From the same table, we can see that the Bartlett's test of Sphericity is significant. That is, its associated probability is less than 0.05 . In fact, it is actually 0.000 . It is small enough to reject the hypothesis. This means that the correlation matrix is not an identity matrix. It is concluded that the relationship among variables is strong. It is a good idea to proceed a factor analysis for the data.

\subsection{Exploratory factor analysis}

In order to separate the dimensions of each construct, Exploratory Factor Analysis (EFA) with varimax rotation was performed separately on RBV factors and SCA criteria. In the course of the validation process, three items (3 items from SCA factors) were found to have unacceptably low factor loadings of less than 0.5 on their respective unobserved hypothetical or latent variable, which were subsequently removed. The internal reliability is evaluated of scales by Cronbach's alpha (C- $\alpha)$. The result has shown that the Cronbach's alpha value ranges between 0.815 to 0.940 for RBV factors, 0.844 for SCA of market entered, 0.777 SCA of customer centered and 0.717 for finance centered indicating the measurement of the variables are well above the acceptable threshold of 0.70 according to Nunnally and Bernstein (1994).

\subsection{Confirmatory factor analysis}

A confirmatory factor analysis (CFA) is performed to evaluate the overall measurement model. In order to evaluate the validity of measurement model, convergent and discriminant validity were evaluated. Convergent validity, along with discriminant validity, is a subtype of construction validity. Convergent validity can be estimated using correlation coefficients. Convergent validity is concerned with the degree that the both assessments of constructs theoretically and actually should be related (Campbell, 1959). A successful evaluation of convergent validity shows that a test of a concept is highly correlated with other tests designed to measure theoretically similar concepts. A convergent validity has been tested by assessing factor loadings, which should be significant and exceed 0.5 , composite reliabilities (CR) which should exceed 0.7 , and the average variance extracted (AVE) that should be more than 0.5 for all constructs (Fornell \& Larcker, 1981). In our model, all the factor loadings and composite reliabilities fall in the acceptable ranges and are significant at the 0.001 level. Factor loadings range from 0.59 to 1.00 and 0.52 to 0.94 , Composite reliabilities (CR) range from 0.857 to 0.955 and 0.703 to 0.851 , AVE ranges from 0.547 to 0.835 and 0.556 to 0.659 for RBV, SCA, respectively. The results show that our model meets the convergent validity criteria. Tables 1 and 2 show the mean, SD, factor loading, AVE, CR and C- $\alpha$ of every constructs. Convergent validity can be established if two similar constructs correspond with one another, while discriminant validity applies to two dissimilar constructs that are easily differentiated. A successful evaluation of discriminant validity shows that a test of a concept is not highly correlated with other tests designed to measure theoretically different concepts (Kline, 2005). Fornell and Larcker's approach has been used to assess discriminant validity. In this approach, the AVE for each construct should be higher than the squared correlation between the construct and any of the other constructs. Table 3 and 4 indicate that the measurement model has satisfactory discriminant validity. In the tables, diagonal elements in italics are the AVE and off-diagonal elements are the squared correlations between constructs. It is obvious that each diagonal element is higher than respective off-diagonal elements. 
Therefore, all constructs in the measurement model were judged as having adequate discriminant validity.

\section{Table 1}

\section{Results of CFA and internal reliability testing \& $\mathrm{K}-\mathrm{M}-\mathrm{O}$ measure for RBV}

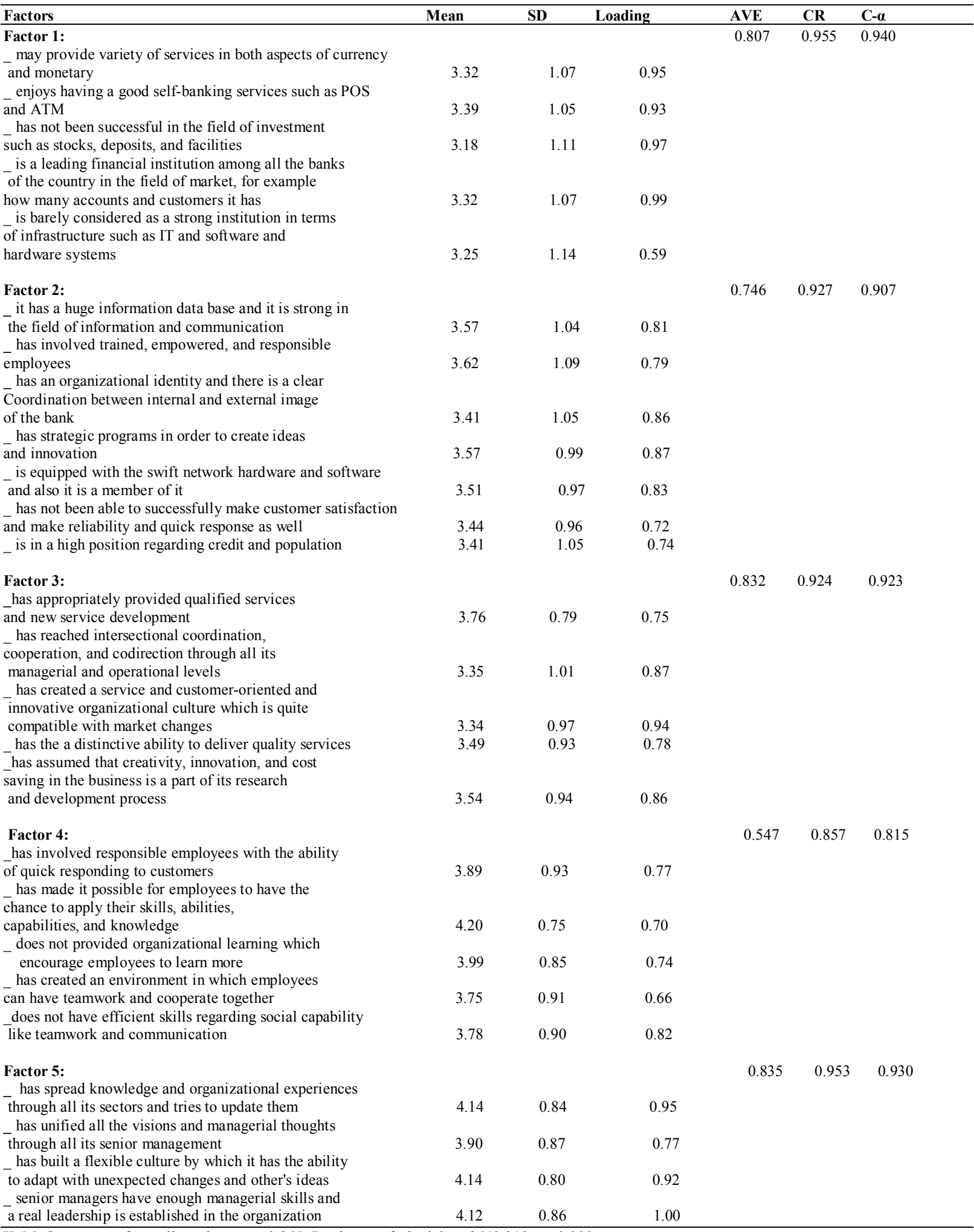

$\mathrm{K}-\mathrm{M}-\mathrm{O}$ measure of sampling adequacy $=0.865 ;$ Bartletttestofsphericity $=2643.219 ; \mathrm{p}<0.000$. 
Table 2

Results of CFA and internal reliability testing \& $\mathrm{K}-\mathrm{M}-\mathrm{O}$ measure for SCA

\begin{tabular}{|c|c|c|c|c|c|c|}
\hline Factor & Mean & SD & Loading & AVE & CR & $\mathrm{C}-\alpha$ \\
\hline Factor 1: & & & & 0.522 & 0.874 & 0.844 \\
\hline $\begin{array}{l}\text { Integrate performances to find the highest position among all } \\
\text { competitors }\end{array}$ & 3.70 & 0.985 & 0.69 & & & \\
\hline _Focusing on market growth and market share indicator & 3.75 & 0.974 & 0.73 & & & \\
\hline _Successful in effective in the market & 3.42 & 1.051 & 0.84 & & & \\
\hline $\begin{array}{l}\text { Providing a socially complicated environment which, it is difficult for } \\
\text { competitors to imitate }\end{array}$ & 3.58 & 0.930 & 0.71 & & & \\
\hline Fully committing to the society and tries to create value for that & 3.38 & 0.893 & 0.68 & & & \\
\hline $\begin{array}{l}\text { Integration and re-formulation of services and create new services } \\
\text { faster than competitors }\end{array}$ & 3.47 & 0.819 & 0.67 & & & \\
\hline Factor 2: & & & & 0.669 & 0.810 & 0.777 \\
\hline $\begin{array}{l}\text { Attractive offers the customers are not superior compared to } \\
\text { competitors }\end{array}$ & 3.27 & 1.067 & 0.66 & & & \\
\hline _Providing efficient services with quality and flexibility & 3.32 & 1.104 & 0.92 & & & \\
\hline $\begin{array}{l}\text { Investing in customer loyalty and satisfaction and create a positive } \\
\text { impression }\end{array}$ & 3.03 & 1.118 & 0.85 & & & \\
\hline Factor 3: & & & & 0.639 & 0.811 & 0.717 \\
\hline Profit rate is higher than the industry average & 3.30 & 0.922 & 0.58 & & & \\
\hline Increasing the efficiency in the financial processes and save costs & 3.60 & 0.991 & 0.97 & & & \\
\hline
\end{tabular}

Table 3

Discriminant validity analysis for RBV

\begin{tabular}{lccccc}
\hline Factors & TA & ITA & HRC & EC & MC \\
\hline TA & 0.807 & & & & \\
ITA & 0.129 & 0.746 & & & \\
HRC & 0.062 & 0.518 & 0.832 & 0.547 & 0.835 \\
EC & 0.067 & 0.562 & 0.260 & 0.115 & 0.102 \\
MC & 0.026 & 0.221 & 0.82 & & \\
\hline
\end{tabular}

Table 4

Discriminant validity analysis for SCA

\begin{tabular}{lccc}
\hline Factors & SCAM & SCAC & SCAF \\
\hline SCAM & 0.522 & & \\
SCAC & 0.176 & 0.669 & 0.636 \\
SCAF & 0.250 & 0.231 & \\
\hline
\end{tabular}

\subsection{The structural model}

Fig. 3 exemplifies the proposed structural model showing the association between the five and three dimensions of RBV and SCA, respectively. To examine the model, conventional maximum likelihood estimation approaches were applied. It is assessed the measurement model fit by evaluating: (1) absolute fit indices including observed normed $\chi^{2}\left(\chi^{2} / \mathrm{df}\right)$, goodness of fit index (GFI), adjusted goodness-of-fit index (AGFI) and adjusted goodness-of-fit index (AGFI); (2) Comparative fit indices including normed fit index (NFI), and comparative fit index (CFI); and (3) parsimonious fit indices including parsimony goodness-of-fit index (PGFI) and parsimony normed fit index (PNFI) and the root mean square error of approximation (RMSEA). The summary results of the structural equation modelling technique are shown in Table 6. Examples of the fundamental measures are the ratio of $\chi^{2}$ statistics to the degree of freedom (df), normed fit index (NFI), comparative fit index (CFI), goodness-of-fit index (GFI) and the root mean square error of approximation (RMSEA). Table 6 summarized the results of CFA models, all the model-fit indices are well above their common acceptable levels in which $\chi^{2} / \mathrm{df}$ was less than 3.0 and greater than 0.90 for GFI, AGFI, CFI and NFI as suggested by Bagozzi and Yi (1988), with RMSEA less than 0.08 according to Browne and 
Cudeck (1993), suggesting that the CFA models fit well. In their studies, Anderson and Gerbing (1988) suggest that values greater than 0.90 are desired for GFI, CFI, AGFI, and NFI while Browne and Cudeck (1993) required values less than 0.08 for RMSEA. Based on Table 5, the ratio of $\chi^{2}$ statistics to the degree of freedom for our model was 1.762. The value of the remaining fit indices include the GFI $=0.93$; $\mathrm{AGFI}=0.91$; $\mathrm{CFI}=0.95$; $\mathrm{NFI}=0.99$; and RMSEA $=0.068$ ). All the modelfit indices are well above their common acceptable levels, suggesting that the structural model fits well. Therefore, we can conclude that the model fits the data well and thus is able to explain the research hypotheses.

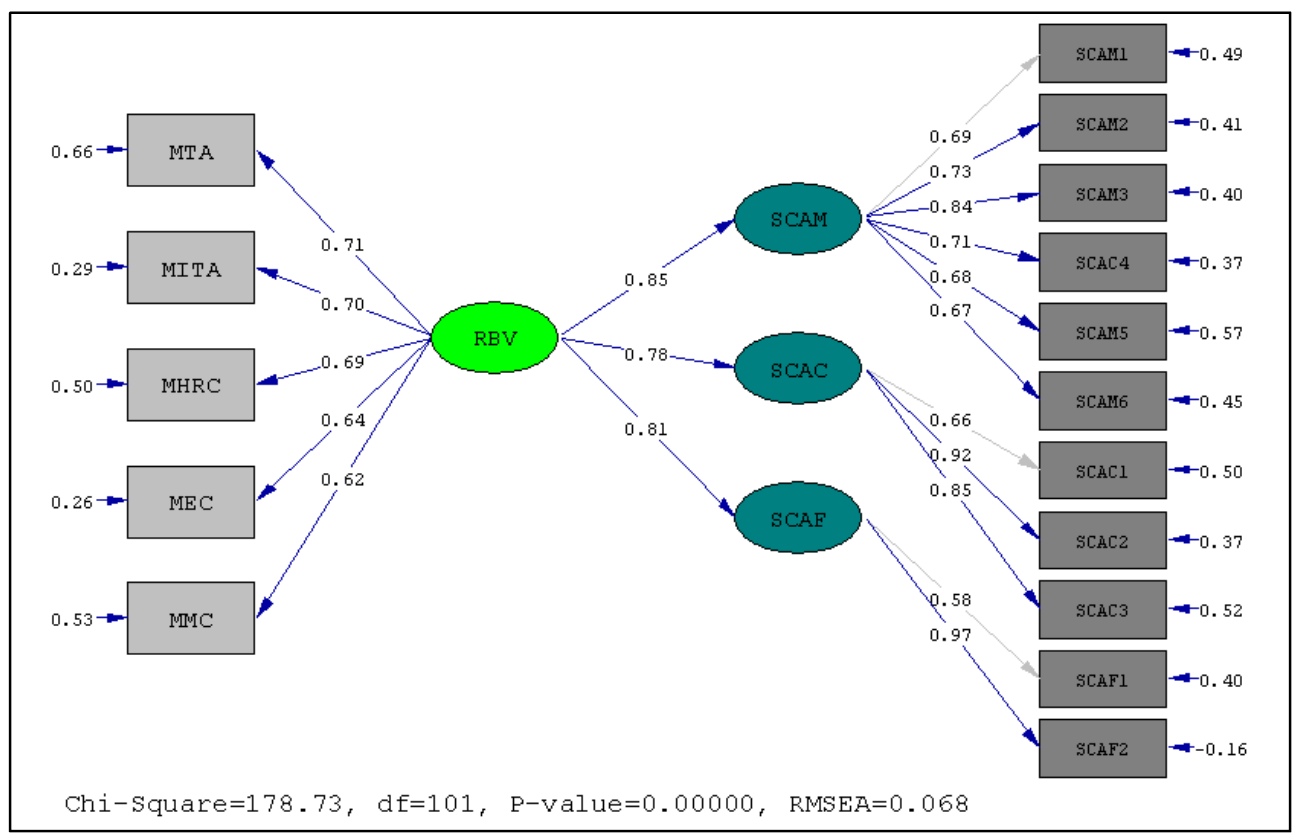

Fig. 3. Structural Relationship model between RBV and SCA

Table 5

Overall fit indices of the CFA model

\begin{tabular}{lcc}
\hline Fit index & Scores & Recommended cut-off value \\
\hline Absolute fit Indices & & \\
X $/$ df & 1.762 & $\leq 3$ \\
GFI & 0.93 & $\geq 0.9 ; \geq 0.8$ \\
AGFI & 0.91 & $\geq 0.9 ; \geq 0.8$ \\
Comparative fit Indices & & $\geq 0.9$ \\
NFI & 0.95 & $\geq 0.9$ \\
CFI & 0.99 & $\leq 0.08 ; \leq 0.1$ \\
Parsimonious fit Indices & & The higher, the better \\
RMSEA & 0.068 & The higher, the better \\
PGFI & 0.88 & \\
PNFI & 0.90 &
\end{tabular}

\subsection{Hypothesis testing}

In the hypothesis testing stage, the proposed hypotheses were examined by using the Structural Equation Modeling (SEM) technique. The findings of Table 6 for $\mathrm{H}_{1}$ (RBV to SCAM; estimate: 0.85; $\mathrm{p}<0.000$ ) implies that RBV has a positive and significant relationship with SCAM in MBI. By adopting the suggested RBV practices, firms will be better able to improve on the level of SCAM through a more systematic approach. Pertaining to $\mathrm{H}_{2}(\mathrm{RBV}$ to SCAC; estimate: $0.78 ; \mathrm{p}<0.000)$, the 
findings revealed that there is a positive relationship between the dimensions of RBV and SCAC. This result is similar to Samat et al. (2006)'s study on the Malaysian service firms, in which the result revealed that management practices such as customer focus, continuous improvement and empowerment has the impact on service quality followed by organizational performance. For the third hypothesis, $\mathrm{H}_{3}(\mathrm{RBV}$ to SCAF; estimate: 0.81 ; $\mathrm{p}<0.000)$, the results were significant, implying that there is a significant relationship between RBV and SCAF.

\section{Table 6}

Standardized path coefficients

\begin{tabular}{cccc}
\hline Hypotheses & Estimate & $\mathrm{p}$-value & Remarks \\
\hline $\mathrm{H}_{1}$ & 0.85 & $<0.000$ & Supported \\
$\mathrm{H}_{2}$ & 0.78 & $<0.000$ & Supported \\
$\mathrm{H}_{3}$ & 0.81 & $<0.000$ & Supported \\
\hline
\end{tabular}

\section{Conclusions}

This study investigated the associations between RBV and SCA for the banking industry. This paper served as empirical evidence contributing to the attributes of RBV, which could be seen on SCA in three areas including the market, costumer and finance. From the analysis, it was shown that RBV contributes significantly and positively to SCA. In other words, RBV implementation can improve the SCA of the MBI. That study supported the strong positive linkage between RBV and SCA since RBV can mediate the firm's VRIN resources to improve performance and reach sustainable competitive advantage. Thus, once RBV practices are in place, market needs can be identified easily and marketing strategy can be further improved, creating values for the customers and accordingly, increase company profits. In other words, market-centered banks have the ability to understand their market targets better. They are more committed to provide superior service to their customers. In addition, their efforts can lead to the provision of high quality service, which will then result in enhanced company performance. Generally, market-centered service firms are better able to meet the needs and expectations of their customers by providing superior service quality. In summary, when RBV dimensions are present in the bank, Banks will be prompt, proper and reliable, thus enhancing the assurance of the bank's services towards the customers. Consequently, increase their profits and productivity and reach sustainable competitive advantage.

\section{Implications of the study}

The empirical findings of this study are crucial to both RBV and SCA and practitioners. From theoretical viewpoint, this study has undoubtedly contributed to the existing literature by providing a better understanding on the proposed structural relationships between RBV and SCA, where the structural relationship between constructs can be determined using SEM, which is more superior to regression analysis. As far as the proposed structural model is concerned, this study offers some evidence for a positive effect of RBV practices on SCA. From a managerial perspective, the findings of the current study guide the banks to a better understanding of the importance of RBV in their managerial actions in becoming a truly market, customer and finance center. Hence, it is imperative for service providers to devote more attention to embrace RBV as a vital management tool for improving competitiveness. Put it simply, in a view of the highly competitive service environment, service practitioners should emphasize on RBV as a feasible change management tool to achieve a greater degree of SCA within their banks. Consequently, banks should constantly monitor the competitive service markets and response to changes better than their rivals do. Furthermore, this study shows that the role of RBV has expanded and contributed to SCA. Hence, RBV practitioners should take full advantage of quality management to enhance the SCA. In doing so, top management 
must ensure a close cooperation and coordination among component of RBV in meeting the everchanging customer necessities. From the methodological perspective, the hypotheses formulated were measured and tested using the SEM approach. This method proved to be far more superior to regression analysis. Firstly, while SEM approach supplies statistical competency and provides a definite method to deal with multiple relationships simultaneously, multiple regression analysis does not. Secondly, as SEM is capable of testing the relationships comprehensively, it has moved from exploratory factor analysis to confirmatory factor analysis. Thirdly, the unobserved concepts and the measurement error in the estimation process are also taken into the account with the use of the SEM practice (Kline, 2005). Given the many advantages of SEM, coupled with the support of many researchers stating that such an approach is a useful methodological assessment tool for many measurement models (Bollen, 1989), Therefore SEM was chosen to test the structural relationships between the four constructs of RBV, MSCA, CSCA, and FSCA.

\section{References}

Alrubaiee, L., \& Al-Nazer, N. (2010). Investigate the impact of relationship marketing orientation on customer loyalty: the customer's perspective. International Journal of Marketing Studies, 2(1), P155.

Akio, T. (2005). The Critical assessment of the resource- based view of strategic management: The source of heterogeneity of the firm. Ritsumeikan International Affairs Journal, 3, 125-150.

Akroush, M. N., \& Al-Mohammad, S. M. (2010). The effect of marketing knowledge management on organizational performance: An empirical investigation of the telecommunications organizations in Jordan. International journal of emerging markets, 5(1), 38-77.

Ambrosini, V., \& Bowman, C. (2009). What are dynamic capabilities and are they a useful construct in strategic management?. International Journal of Management Reviews, 11(1), 29-49.

Amini, A., Darani, M., Afshani, M., \& Amini, Z. (2012). Effectiveness of marketing strategies and corporate image on brand equity as a sustainable competitive advantage. Interdisciplinary Journal of Contemporary Research in Business, 4(2), 192-205.

Amit, R., \& Schoemaker, P. J. (1993). Strategic assets and organizational rent.Strategic management journal, 14(1), 33-46.

Andersen, H. (2013). China-Denmark cooperation. Working paper, Aalborg University.

Anderson, J.C., \& Gerbing, D.W. (1988). Structural equation modeling in practice: a review and recommended two-step approach. Psychological Bulletin, 103(3), 411-423.

Bagozzi, R.P., \& Yi, Y. (1988). On the evaluation of structural equation models. Journal of Academy of Marketing Science, 16(1), 74-94.

Barney, J.B. (1986). Types of competition and the theory of strategy: Toward an integrative framework. Academy of Management Review, 11(4), 791-800.

Barney, J.B. (1988). Returns to bidding firms in mergers and acquisitions: Reconsidering the relatedness hypothesis. Strategic Management Journal, Special Issue 9, 71-78.

Barney, J.B. (1991). Firm resources and sustained competitive advantage. Journal of Management 17(1), 99-120.

Barney, J.B. (1995). Looking inside for competitive advantage. Academy of Management Executive 9(4), 49-61.

Barney, J.B. (2000). Firm resources and competitive advantage. Advances in Strategic Management, $17,203-227$.

Barney, J.B. (2001a). Is the resource-based view a useful perspective for strategic management research? Yes. Academy of Management Review, 26(1), 41-56.

Barney, J.B. (2001b). Resource-based Theories of Competitive Advantage: A ten-year Retrospective on the Resource-based View. Journal of Management, 27(6), 643-650. 
Barney, J.B., \& Arikan, A.M. (2001). The resource-based view: Origins and implications. In Blackwell Handbook of Strategic Management, Hitt MA, Freeman RE, Harrison JS (eds). Oxford, U.K., 124-188.

Bollen, K.A. (1989). A new incremental fit index for general structural equation models. Sociological Methods and Research, 17(3), 303-316.

Browne, M.W., \& Cudeck, R. (1992). Alternative Ways of Assessing Model Fit. Sociological Methods Research, 21(2), 230-258.

Burns, P. (2008). Corporate Entrepreneurship: Building the Entrepreneurial Organization, Palgrave Macmillan: New York.

Campbell, D.T. (1959). Convergent and discriminant validation by the multitrait-multimethod matrix. Psychological Bulletin, 56(2), 81-105.

Carlos, M.P., Sousa, E.R., \& Fernando, L. (2010). The key role of managers' values in exporting: Influence on customer responsiveness and export performance. Journal of International Marketing, 18(2), 1-19.

Christensen, CM. (2001). The past and future of competitive advantage. MIT Sloan Management Review, 42(2), 105-119.

Chunxia, Y.U. (2012). Agent-based supplier model for products with synergy effect. The university of Hong Kong.

Conner, K.R. (1991). A historical comparison of resource based theory and five schools of thought within industrial organization economics: Do we have a new theory of the firm? Journal of Management, 17(1), 121-154.

Dierickx, J., \& Cool, K. (1989). Asset stock accumulation and sustainability of competitive advantage. Management Science, 35(12), 1504-1511.

Evans, M., Jamal, A., \& Foxall, G. (2009). Consumer Behavior. West Sussex, England: John Wiley \& Sons Ltd.

Fornell, C., Larcker, D.F. (1981). Evaluating structural equation models with unobservable variables and measurement error. Journal of Marketing Research 18(1), 39-50.

Gupta, S., Woodside, A., Dubelaar, C., \& Bradmore, D. (2009). Diffusing knowledge-based core competencies for leveraging innovation strategies: Modeling outsourcing to knowledge process organizations (KPOs) in pharmaceutical networks. Industrial Marketing Management, 38(2), 219 227.

Grant, R. (1996). Toward a knowledge-based theory of the firm. Strategic Management Journal, Special Issue 17, 109-122.

Hamidizadeh, M.A., \& Taheri, M. (2013). A comprehensive literature review in competitive advantages of businesses. Asian Journal of Research in Marketing 2(6), 76-97.

Holliday, C. (2001). Sustainable growth the Du Pont way. Harvard Business Review, 79(8), 129-135.

Hoopes, D.G., Madsen, T.L., \& Walker, G. (2003). Why is there a resource-based view? Toward a theory of competitive heterogeneity. Strategic Management Journal, 24(10), 889-902.

Johnson, G., Scholes, K., \& Whittington, R. (2008). Exploring corporate strategy text and cases. Financial Times (FT): Prentice Hall.

Jones, G.R., \& Hill, C.W.L. (2013). Theory of strategic management with cases. Canada: SouthWestern, Cengage Learning.

Josiah, A. (2013). Business leverages on strategic information systems in Nigeria. International Journal of Learning \& Development 3(1), 212-220.

King, A.W. (2007). Disentangling interfirm and intrafirm causal ambiguity: a conceptual model of causal ambiguity and sustainable competitive advantage. The Academy of Management Review, $32(1), 156-178$.

Kline, R.B. (2005). Principles and Practice of Structural Equation Modeling. Guilford Press: New York.

Kozlenkova, I.V., Samaha, S.A., \& Palmatier, R.W. (2014). Resource-based theory in marketing. Journal of the Academy of Marketing Science, 42(1), 1-21. 
Li, J.J., \& Zhou, K.Z. (2010). How foreign firms achieve competitive advantage in the Chinese emerging economy: Managerial ties and market orientation. Journal of Business Research, 63(8), 856-862.

Lippman, S.A., \& Rumelt, R.P. (1982). Uncertain Imitability: An analysis of interim differences in efficiency under competition. The Bell Journal of Economics, 13(2), 418-438.

Ljungquist, U. (2008). Specification of core competence and associated components: A proposed model and a case illustration. European Business Review, 20(1), 73-90.

Lockett, A., Thompson, S., \& Morgenstern, U. (2009). The development of the resource-based view of the firm: A critical appraisal. International Journal of Management Reviews, 11(1), 9-28.

Mahoney, J.T., \& Pandian, J.R. (1992). The resource-based view within the conversation of strategic management. Strategic Management Journal, 13(5), 363-380.

Makadok, R. (2001). Toward a synthesis of the resource-based and dynamic-capability views of rent creation. Strategic Management Journal, 22(5), 387-401.

Marr, B., \& Moustaghfir, K. (2004). Knowledge management, intellectual capital, and dynamic capabilities: What is the link? In proceedings of the 5th European conference on knowledge management. http://academic-conferences.org/.../ECIE10-abs.

Nunnally, J.C., \& Bernstein, I.H. (1994). Psychometric Theory. McGraw-Hill: New York.

Oliver, RL. (1999). Whence consumer loyalty? Journal of Marketing, special issue, 63, 33-44.

Pearce, J.A., \& Robinson, R.B. (2000). Strategic management formulation, Implementation, and Control. McGraw-Hill: Boston.

Penrose, E.T. (1959). The Theory of the Growth of the Firm. John Wiley \& Sons: New York.

Peteraf, M.A. (1993). The cornerstones of competitive advantage: A resource-based view. Strategic Management Journal, 14(3), 179-91.

Peteraf, M.A., \& Bergen, M.E. (2003). Scanning dynamic competitive landscapes: A market-based and resource-based framework. Strategic Management Journal, 24(10), 1027-1041.

Porter, M.E. (1996). What is strategy?. Harvard Business Review, 74(6), 61-78.

Prahalad, C.K., \& Hamel, G. (1990). The core competence of the corporation. Harvard Business Review, 68(3), 79-91.

Razali, N.M., \& Wah, Y.B. (2011). Power comparisons of Shapiro-Wilk, Kolmogorov-Smirnov, Lilliefors and Anderson-Darling tests. Journal of Statistical Modeling and Analytics, 2(1), 21-33.

Reed, R., \& Defillippi, R. (1990). Casual ambiguity, barriers to imitation, and sustainable competitive advantage. Academy of Management Review, 15(1), 88-102.

Rijamampianina, R., Abratt, R., \& February, Y. (2003). A framework for concentric diversification through sustainable competitive advantage. Management Decision, 41(4), 362-371.

Rindova, V., Ferrier, W.J., \& Wiltbank, R. (2010). Value from gestalt: how sequences of competitive actions create advantage for firms in nascent markets. Strategic Management Journal, 31(13), $1474-1497$.

Rose, R.C., Abdullah, H., Ismad, A.I. (2010). A review on the relationship between organizational resources. Competitive Advantage and Performance, 3(11), 488-499.

Rugman, A.M., \& Verbeke, A. (2002). Edith penrose's contribution to the resource based view of strategic management. Strategic Management Journal, 23(8), 769-780.

Rumelt, R. (1991). How much does industry matter? Strategic Management Journal, 12(3), 167-185.

Samat, N., Ramayah, T., \& Saad, N.M. (2006). TQM practices, service quality, and market orientation: some empirical evidence from developing country. Management Research News, 29(11), 713-728.

Seetharaman, A., Nadzir, Z.A.B.M., \& Gunalan, S. (2001). A conceptual study on brand valuation, Journal of Product and Brand Management, 10(4), 243-256.

Talaja, A. (2012). Testing VRIN framework: resource value and rareness as sources of competitive advantage and above average. Management: Journal of Contemporary Management, 17(2), 51-64.

Thompson, A., \& Peteraf, M.A., Gamble, J.E., \& Strickland, A.J. (2012). Crafting and executing strategy concepts and readings. McGraw Hill Irwin: New York. 
Trung, T.D.H. (2014). Obtaining sustainable competitive advantage from customer loyalty: A perspective of marketing-mix strategy and corporate social responsibility. Working paper, Department of international business administration, College of Business Chinese Culture University.

Villalonga, B., \& Amit, R. (2006). How do family ownership, management, and control affect firm value? Journal of Financial Economics, 80(2), 385-417.

Wan, W.P., Hoskisson, R.E., Short, J.C., \& Yiu, D.W. (2011). Resource-based theory and corporate diversification: Accomplishments and opportunities. Journal of Management, 37(5), 1335-1368.

Wernerfelt, B. 1984. A resource-based view of the firm. Strategic Management Journal 5(2): 171-80.

Wernerfelt, B., \& Montgomery, C.A. (1986). What is an attractive industry? Management Science 32(10), 1223-1230.

White, B.A., \& Moraschinelli, E. (2009). The Pursuit of sustainable competitive Advantage - A profile of the Starbucks Corporation. Working paper, International Business and Entrepreneurship, Malardalen University.

Zook, C., \& Allen, J. (2001). Profit from the core: growth strategy in an era of turbulence. Harvard Business School Publishing: Boston, MA. 